\title{
Psychosocial Risk Factors on Mining Workers Processing Copper and Gold Minerals during Covid-19 Pandemic
}

\author{
Faktor Risiko Psikososial Pada Pekerja Tambang Pengolahan Mineral Tembaga \\ dan Emas pada Kondisi Pandemi Covid-19
}

\author{
Khaerani S. Lestari' ${ }^{1}$, Aditya F. Muhamad ${ }^{1}$, Arif Susanto ${ }^{2,3,4}$, Edi K. Putro ${ }^{1}$, John C. Wilmot ${ }^{5}$, Yenni \\ M. Savira ${ }^{1}$, Aprilia Listiarini ${ }^{1}$, Donny Zulfakar ${ }^{6}$, Stevan D. A. M. Sunarno ${ }^{7}$ \\ ${ }^{1}$ Resource Management Department, Concentrating Division of PT Freeport Indonesia, Tembagapura 99960 \\ Indonesia \\ ${ }^{2}$ Green Technology Research Center, Doctorate Program in Environmental Science, School of Postgraduate \\ Studies Universitas Diponegoro, Semarang 50241 Indonesia \\ ${ }^{3}$ Department of Environmental Engineering, Faculty of Civil and Planning Engineering, Universitas \\ Kebangsaan Republik Indonesia, Bandung, West Java 40268 Indonesia \\ ${ }^{4}$ Industrial Hygiene \& Environmental Health, Resource Management, Concentrating Division of PT Freeport \\ Indonesia, Tembagapura 99960 Indonesia \\ ${ }^{5}$ Mill Operation Department, Concentrating Division of PT Freeport Indonesia, Tembagapura 99960 \\ Indonesia \\ ${ }^{6}$ Technical Services Department, Concentrating Division of PT Freeport Indonesia, Tembagapura 99960 \\ Indonesia \\ ${ }^{7}$ Department of Occupational Health and Safety, Faculty of Public Health, Universitas Indonesia, Depok, \\ West Java Indonesia
}

\begin{abstract}
Introduction: In the era of the Covid-19 pandemic, psychosocial issues as part of health and safety have become a popular mental health issue, particularly among gold and copper miners. This situation has led some companies to fire their unskilled and unproductive workers to minimize the production costs. However, there is no specific regulation for the workers that could be a barrier of this unpredicted situation. This condition mostly becomes a negative stressor for the workers at the jobsite. At some point, it develops to a critical health and safety condition known as risky and unhealthy behavior that brings to fatality. The aim of this research is to analyze the psychosocial risk factors that adversely affect the psychology of copper and gold mining workers during the pandemic. Method: This is a cross-sectional study with COPSOQ III, used to identify factors contributing to workers' psychology, while Dolan \& Arsenault's questionnaire was used to analyze stress symptoms, with a Cronbach $\alpha$ value of $0.83-0.84$. Results: Multivariate tests were conducted on the variables of work experience, body mass index, marital status, emotional demands, vertical trust, and organizational justice. Significance values were obtained for the variables of work experience $(0.590$ body mass index (0.517), marital status $(0.122)$, emotional demands $(0.187)$, vertical trust $(0.000)$, and organizational justice $(0.119)$. Of the six variables, only vertical trusthad a significant value. Conclusion: Psychological risk factors on copper and gold mining workers during the pandemic are only influenced by a vertical trust.
\end{abstract}

Keywords: COPSOQ III, leadership, pandemic, psychosocial, vertical trust

\begin{abstract}
ABSTRAK
Pendahuluan: Di era pandemi covid-19, isu psikososial sebagai bagian dari kesehatan dan keselamatan menjadi isu kesehatan mental yang populer, khususnya di kalangan penambang emas dan tembaga. Situasi ini membuat beberapa industri memutus hubungan kerja pada pekerja yang tidak terampil dan tidak produktif untuk meminimalkan biaya produksi, sementara itu tidak ada peraturan khusus untuk pekerja yang dapat menjadi penghalang situasi yang tidak terduga ini. Kondisi ini sebagian besar menjadi stressor negatif bagi pekerja di lokasi kerja. Pada titik tertentu, itu berkembang menjadi kondisi kesehatan dan keselamatan kritis yang dikenal sebagai perilaku berisiko dan tidak sehat yang membawa kematian. Penelitian ini bertujuan untuk menganalisis faktor risiko psikososial yang berdampak buruk pada psikologi pekerja tambang tembaga dan emas selama masa pandemi. Metode: Ini adalah studi cross-sectional dengan copsoq III yang digunakan untuk mengidentifikasi faktor-faktor yang berkontribusi terhadap psikologi pekerja, sedangkan kuesioner Dolan \& Arsasault digunakan untuk menganalisis gejala stres, dengan nilai a Cronbach sebesar
\end{abstract}


0,83-0,84. Hasil: Uji multivariat dilakukan pada variabel pengalaman kerja, indeks massa tubuh, status perkawinan, tuntutan emosional, kepercayaan vertikal, dan keadilan organisasi. Nilai signifikansi diperoleh untuk variabel pengalaman kerja (0,590) indeks massa tubuh $(0,517)$, status perkawinan $(0,122)$, tuntutan emosional $(0,187)$, kepercayaan vertikal (0,000), dan keadilan organisasi (0,119). Dari keenam variabel hanya vertikal kepercayaan memiliki nilai yang signifikan. Simpulan: Faktor risiko psikologi pada pekerja tambang tembaga dan emas selama masa pandemic hanya dipengaruhi oleh kepercayaan vertikal.

Kata kunci: COPSOQ III, kepemimpinan, pandemi, psikososial, kepercayaan vertikal

\section{Corresponding Author:}

Khaerani Suci Lestari

Email: khaeranisucilestari@gmail.com

Telephone: +6281291108394

\section{INTRODUCTION}

The World Health Organization (WHO) defines the workplace as a space with physical, psychological, social, and organizational conditions that protect and enhance the overall health of members (Stoewen, 2016). According to Law No.1 of 1970 on Work Safety, the workplace is any closed, open, temporal or permanent room/field where laborers frequently enter to carry out businesses. Furthermore, it is stated that the dangers associated with a workplace consist of chemical, physical (mechanical, electrical, loose energy), biological, ergonomic, and psychosocial factors (Lestari et al., 2020). Based on the Ministry of Manpower of the Republic of Indonesia (2018) on Occupational Safety and Health in the Work Environment, psychosocial factors affect employment activities, caused by interpersonal relationships in the workplace, roles and responsibilities towards work.

Psychosocial problems are common in the mining industry, and these affect workers' welfare as well as the safety of the workplace (International Council on Mining \& Metals, 2020). Therefore, companies need to strive to support physical and psychological safety, which is also driven by high costs, increased periods of absence, and high payments of medical, legal, and other claims (Davidescu et al., 2020).

Several studies have found significant cost losses due to psychosocial problems. For instance, The Minerals Council of Australia in accordance with the Scheme for Psychosocial and Wellbeing stated that companies lose between \$320-450 million per year due to worker absenteeism (Carlisle and Parker, 2014; The Australian Institute of Health and Welfare, 2021; Minerals Council of Australia, 2015). According to the National Psychosocial and Wellbeing Survey released by the Australian Bureau of Statistics, one in five Australian adults is likely to have psychosocial problems for at least 12 months (The Australian Institute of Health and Welfare, 2021). The estimated loss incurred by a country due to psychosocial factors ranges from \$ 221.3 million to $\$ 187$ billion, with an individual loss of $\$ 17.79$ to $\$ 1,211.8$ (Hassard et al., 2018). Psychosocial problems do not only occur in the mining industry as individuals also experience them due to prolonged time away from home, long working hours, economic demands, reduced number of workers, and social isolation (International Council on Mining \& Metals, 2020; Minerals Council of Australia, 2015; Bowers et al., 2018)

Companies need to take adequate care of workers with psychological problems and ensure those affected are properly treated because they are essential factors to the success of any organization. Generally, mining companies are located in remote areas with limited access, so with the emergence of the Covid-19 pandemic, employees are at risk of transmitting the virus to other people, due to communication with the outside environment. Currently, several mining companies in Indonesia have been forced to shut down due to the increasing number of employees infected with Covid-19 (Naciri et al., 2020).

The World Health Organization has issued a Covid-19 guideline that regulates the implementation of hygiene protocols in public facilities. This has forced several mining companies to close their recreational facilities, such as karaoke, fitness centers, sports fields, swimming pools, restaurants, etc. The closure of these facilities, which are intended as recreational centers for employees onsite tends to affect their psychology negatively. Furthermore, the impact of the restrictions on public facilities and health protocols implemented by the local government has also affected the periodic leave system in several mining companies. These restrictions also consider the economic factors, such as additional costs for the mandatory PCR or rapid test before travelling and the availability of transportation, which needs to limit the capacity up to $50 \%$. Several mining companies located in remote 
areas have also been forced to extend the periodic leave system for their employees (Ramdoo, 2020).

The Covid-19 pandemic has forced the mining industry to rapidly adapt to changes, with several companies conducting internal restrictions to maintain production stability using available health facilities. One of the methods used is determining and mandating the non-essential employees to work from outside the jobsite. Some companies have also terminated the employment contracts of some nonessential workers. This is certainly a stressor for employees who are currently still actively working on the jobsite. Therefore, this study aims to explain the psychosocial description and the factors that contribute to the psychology of copper and gold ore processing workers during the Covid-19 pandemic.

\section{METHODS}

This research has been tested by the Health Research Ethics Commission of the Hang Tuah School of Health, Pekanbaru with the ethical test number 209/KEPK/STIKes-HTP/IV2021. This research used a cross-sectional design carried out on mining workers processing copper and gold minerals from May to June 2020 to examine the factors contributing to workers' psychology during the pandemic. The cluster random sampling method was used to obtain data from 109 workers out of a total of 1,332, as shown in Table 1. The instrument used to carry out this research was The Copenhagen Psychosocial Questionnaire COPSOQ III, which identified factors that contribute to the workers' psychology during the pandemic (Burr et al., 2019). Furthermore, the Dolan and Arsenault's questionnaire was used to identify the emotional psychological and behavioral symptoms of stress. The instrument was tested with Cronbach's $\alpha$ results in the range of $0.83-0.84$, while the components of the questionnaire resulted in variables ranging from $0-10$ for each subscale. The components of the questionnaire were also dichotomized using the median of the reference sample as the cutoff point to indicate high and low exposure levels. Meanwhile,

Table 1. The Sample Distribution

\begin{tabular}{lc}
\hline \multicolumn{1}{c}{ Section } & Sample (person) \\
\hline Maintenance & 60 \\
Technical Services & 25 \\
Operation & 18 \\
Resource Management & 6 \\
\hline
\end{tabular}

for emotional, psychological, and behavioral symptoms based on the Dolan and Arsenault's questionnaire, the value was below 4 , which means that the sample was in a normal condition and when it was above four, the sample was in a moderatehigh stress.

Multiple logistic regressions were used to examine the relationship between individual characteristics and psychological factors. In the first step, all variables were entered into the bivariate selection to determine the variables to be included in the multivariate model. Six variables had a p-value $<0.25$, namely work experience, body mass index, marital status, emotional demands, vertical trust, and organizational justice, with the ENTER method used to determine the results of multivariate analysis.

\section{RESULTS}

Table 2 describes the sample characteristics used in this research, with participants more likely to come from contractors, with the same work experience or under five years, had a normal body mass index, and were married. Psychosocial factors are described in Table 3, which shows that there were 17 variables regarding psychosocial factors with a frequency distribution above $50 \%$ in the high classification. These included quantitative demands, work pace, influence at work, development possibility, recognition, role conflict, leadership

Table 2. The Distribution of Demographic Characteristic of the Sample

\begin{tabular}{lcc}
\hline \multicolumn{1}{c}{ Variables } & N (person) & \% \\
\hline Body Mass Index & & \\
Risky & 71 & 65.1 \\
Not Risky & 38 & 34.9 \\
Work Experience & & \\
$>5$ years & 35 & 32.1 \\
$<5$ years & 74 & 67.9 \\
Marital Status & & \\
Single & 31 & 28.4 \\
Married & 78 & 71.6 \\
Employee status & & \\
Company's & 39 & 35.8 \\
Employee & & \\
Contractor's & 70 & 64.2 \\
Employee & & \\
Age & & 39.5 \\
$<35$ years old & 43 & 60.5 \\
$>35$ years old & 66 & \\
\hline
\end{tabular}


Table 3. The Distribution of Psychosocial Factors

\begin{tabular}{|c|c|c|c|c|c|c|c|c|c|}
\hline \multirow[t]{2}{*}{ Variable } & \multicolumn{2}{|c|}{ Low } & \multicolumn{2}{|c|}{ High } & \multirow[t]{2}{*}{ Variable } & \multicolumn{2}{|c|}{ Low } & \multicolumn{2}{|c|}{ High } \\
\hline & n (person) & $\%$ & n (person) & $\%$ & & n (person) & $\%$ & n (person) & $\%$ \\
\hline $\begin{array}{l}\text { Quantitative } \\
\text { demands }\end{array}$ & 48 & 44.0 & 61 & 56.0 & $\begin{array}{l}\text { Meaning of } \\
\text { work }\end{array}$ & 63 & 57.8 & 46 & 42.2 \\
\hline Work pace & 50 & 45.9 & 59 & 54.1 & Predictability & 71 & 65.1 & 38 & 34.9 \\
\hline $\begin{array}{l}\text { Emotional } \\
\text { demands }\end{array}$ & 55 & 50.5 & 54 & 49.5 & Recognition & 51 & 46.8 & 58 & 53.2 \\
\hline $\begin{array}{l}\text { Influence at } \\
\text { work }\end{array}$ & 32 & 29.4 & 77 & 70.5 & Role clarity & 54 & 49.5 & 55 & 50.5 \\
\hline Role conflicts & 48 & 44.0 & 61 & 56.0 & $\begin{array}{l}\text { Job } \\
\text { insecurity }\end{array}$ & 43 & 39.4 & 66 & 60.6 \\
\hline $\begin{array}{l}\text { Quality of } \\
\text { leadership }\end{array}$ & 51 & 46.8 & 58 & 53.2 & Burnout & 46 & 42.2 & 63 & 57.8 \\
\hline $\begin{array}{l}\text { Job } \\
\text { satisfaction }\end{array}$ & 36 & 33.0 & 73 & 67.0 & Stress & 57 & 52.3 & 52 & 47.7 \\
\hline $\begin{array}{l}\text { Work life } \\
\text { conflict }\end{array}$ & 47 & 43.1 & 62 & 56.9 & $\begin{array}{l}\text { Somatic } \\
\text { stress }\end{array}$ & 50 & 45.9 & 59 & 54.1 \\
\hline Vertical trust & 48 & 44.0 & 61 & 56.0 & $\begin{array}{l}\text { Cognitive } \\
\text { stress }\end{array}$ & 63 & 57.8 & 46 & 42.2 \\
\hline $\begin{array}{l}\text { Organizational } \\
\text { justice }\end{array}$ & 61 & 56.0 & 48 & 44.0 & $\begin{array}{l}\text { Depressive } \\
\text { symptoms }\end{array}$ & 53 & 48.6 & 56 & 51.4 \\
\hline $\begin{array}{l}\text { Insecurity } \\
\text { over working } \\
\text { condition }\end{array}$ & 52 & 47.7 & 57 & 52.3 & $\begin{array}{l}\text { Possibilities } \\
\text { for } \\
\text { development }\end{array}$ & 51 & 46.8 & 58 & 53.2 \\
\hline $\begin{array}{l}\text { Social } \\
\text { support from } \\
\text { colleagues }\end{array}$ & 45 & 41.3 & 64 & 58.7 & $\begin{array}{l}\text { Social } \\
\text { support from } \\
\text { supervisor }\end{array}$ & 76 & 69.7 & 33 & 30.3 \\
\hline $\begin{array}{l}\text { Self-rated } \\
\text { health }\end{array}$ & 29 & 26.6 & 80 & 73.4 & $\begin{array}{l}\text { Sleeping } \\
\text { trouble }\end{array}$ & 54 & 49.5 & 55 & 50.5 \\
\hline $\begin{array}{l}\text { Sense of } \\
\text { community at } \\
\text { work }\end{array}$ & 68 & 62.4 & 43 & 39.4 & & & & & \\
\hline
\end{tabular}

Table 4. The Multivariate Analyses of Individual Characteristics and Psychosocial Factors

\begin{tabular}{lcccc}
\hline & Initial Sig. Value & Initial Odds Ratio & Final Sig. Value & Final Odds Ratio \\
\hline Work Experience & 0.089 & 0.336 & 0.590 & 0.313 \\
Body Mass Index & 0.517 & 1.470 & 0.517 & 1.470 \\
Marital Status & 0.101 & 4.195 & 0.122 & 3.372 \\
Emotional Demands & 0.172 & 0.373 & 0.187 & 0.390 \\
Vertical Trust & 0.002 & 9.775 & 0.000 & 14.434 \\
Organizational Justice & 0.116 & 2.656 & 0.119 & 2.602 \\
Constant & 0.034 & 0.006 & 0.017 & 0.006 \\
\hline
\end{tabular}

quality, social support from colleagues, job insecurity, working conditions, job satisfaction, work-life conflicts, vertical confidence, personal health, fatigue, somatic stress, and depressive symptoms.

Table 4 shows the results of multivariate analysis of individual characteristics, psychosocial factors, and vertical trust. Furthermore, vertical trust was the only variable that had a significant relationship with leadership quality, which is one of the components that often appears when the bivariate test is conducted. Apart from leadership factor, psychosocial factors are also interesting factors to study during an emergency situation, such as this 
pandemic era. This can be seen in the significance value below 0.05 and the odds ratio changing by more than $10 \%$.

Statistical analysis showed that there was an insignificant relationship between the variables of work experience, body mass index, marital status, emotional demands, and organizational justice with leadership quality. The results of the analysis from an interpersonal and organizational point of view indicated that only one variable had a significant relationship with leadership quality, namely, vertical trust.

\section{DISCUSSION}

The lack of preparedness to face the Covid19 pandemic has led to various changes in policy. Policies that change frequently cause confusion among employees. The company has carried out various kinds of mitigation to break the chain of distribution in the jobsite area, such as temporarily changing employee leave policies, implementing curfews, prohibiting visits to other employees' accommodation, closing public areas in the jobsite such as gyms, restaurants, and playgrounds. However, these efforts have made vertical trust the biggest issue.

Vertical trust is defined as a dynamic interpersonal relationship between individuals, with unique implications in the workplace. Employees perceive trust in organizations as a global evaluation process, with positive expectations of oneself in risky situations (Jain, 2016; Lewicka and Pec, 2019). Vertical trust is generally more complex than the horizontal one because it involves power and control, which has a significant impact on subordinates (Hasche, Höglund and Mårtensson, 2020).

The relationship and a character-based perspective are used to describe how trust in a leader or supervisor affects performance. These are important variables used to regulate employee relations and interpret managerial behavior (Guinot and Chiva, 2019). Furthermore, the relationship is a character-based perspective, which functions as a decisive performance moderator between leaders and employees (Chen et al., 2018). Trust in leaders is also considered a predictor of team performance because it improves organizational functioning, effectiveness, and performance. Similarly, mutual trust is capable of driving team performance because it requires greater interdependence, initiatives, and positive interactions (Guinot and Chiva, 2019; Carter and Mossholder, 2015).
Employees perceive leaders as those with competence, virtue, and integrity. A leader is meant to perform effectively by influencing others through their excellent competency, genuine concern (virtue) and actions according to their word (integrity) (Engelbrecht, Heine and Mahembe, 2017). Several studies have shown that leadership practices affect the trust of subordinates by providing information about the character or relationship between the subordinates with their leader. Some of the questions that arise are:

Is the leader competent?

Does the leader have integrity?

Does the leader show concern to their subordinates?

Is the leader open and receptive to criticism?

Leaders generate team trust by building knowledge and expertise, as well as providing technical expertise, advice and up-to-date knowledge, such as disseminating newly published technical reports from the Ministry of Energy Mineral Resource. This practice demonstrates the leader's competence, thereby increasing the team's willingness to rely on their professional knowledge, skills and judgment; this will eventually build building dependency-based trust that affects team members' perceptions (Engelbrecht, Heine and Mahembe, 2017; Bligh, 2017).

Leadership is described as an interactive relationship between individuals in which one person exerts more influence (a leader) than others. Successful leaders are those capable of influencing the behavior and activities of group members. Emotional intelligence, communication, empathy, creativity, and vision are all factors that contribute to leader effectiveness. Individuals tend to follow leaders they can trust and make them feel safe. Employee trust in a leader is associated with the leaders' ability to make the employees believe in their words, actions, and decisions. This shows that when trusting a leader, followers become more vulnerable to being influenced by their actions. Given the importance of trust in understanding leadership, it is surprising that the literature on this topic is relatively sparse (Rosari, 2019; Stedham and Skaar, 2019).

Basically, a leader of an organization is expected to be able to change and invite others. Leaders need to use a persuasive approach and positive encouragement in leading the organization and need to be able to provide solutions to problems. Leaders also need to understand their followers' need and make it a stimulus in achieving organizational goals. 
One of the important and often overlooked factor in leadership principles is how leaders can identify and reward their followers (Latif, 2018; Karasel et al., 2018).

It is necessary to develop the leadership potential of all employees in an organization by having strong, responsible and empowered staff for improved performance. Leadership cannot rely solely on the top leaders in the organization, but rather it can be practised at all levels of the organization, irrespective of the job function or length of service of the employees in their positions. Strategic leadership is associated with thinking and acting especially when facing a conflict/challenge, such as changes that occur due to the Covid-19 pandemic. This means that an organization needs to empower employees to become leaders and develop a "leadership mindset" in workers.

\section{CONCLUSION}

This research found that vertical trust was the only psychological risk factors that affected workers, while the other factors were not significant because this research was conducted at the beginning of the Covid-19 pandemic, with many policies changing and employee trust to supervisors decreasing.

\section{ACKNOWLEDGEMENTS}

This study was supported by PT Freeport Indonesia. The authors would like to thank the all parties that have contributed to this research. In particular, the authors would like to thank Mufti Wirawan, Fanny Yuliasari, Saul Pasaribu, and Sandy Basoan for providing advice on developing the questionnaire and collecting data.

\section{REFERENCES}

Bligh, M. (2017) Leadership Today. Edited by S. D. Joan Marques. USA: Springer International Publishing.

Bowers, J. et al. (2018) 'Psychological Distress in Remote Mining and Construction Workers in Australia', Medical Journal of Australia, 208(9), pp. 391-397.

Burr, H. et al. (2019) 'The Third Version of the Copenhagen Psychosocial Questionnaire', Safety and Health at Work, 10(4), pp. 482-503.

Carlisle, K. N. and Parker,A. W. (2014) 'Psychological Distress and Pain Reporting in Australian Coal miners', Safety and Health at Work, 5(4), pp. 203-209.

Carter, M. Z. and Mossholder, K. W. (2015) 'Are We on the Same Page? The Performance Effects of Congruence between Supervisor and Group Trust.', Journal of Applied Psychology, 100(5), pp. 1349-1363.

Chen, Y. et al. (2018) 'Is transformational Leadership always Good for Employee Task Performance? Examining Curvilinear and Moderated Relationships', Frontiers of Business Research in China, 12(1), pp. 117-133.

Davidescu, A. A. M. et al. (2020) 'Work Flexibility, Job Satisfaction, and Job Performance among Romanian Employees-Implications for Sustainable Human Resource Management', Sustainability (Switzerland), 12(15). pp. 1-53

Engelbrecht, A. S., Heine, G. and Mahembe, B. (2017) 'Integrity, Leadership of Ethics, Trust and Work Engagement', Leadership \& Organization Development Journal, 38(6), pp. 765-779.

Guinot, J. and Chiva, R. (2019) 'Vertical Trust Within Organizations and Performance: A Systematic Review,'Human Resource Development Review, 18(2), pp. 196-227.

Hasche, N., Höglund, L. and Mårtensson, M. (2020) 'Intraorganizational Trust in Public Organizations - the Study of Interpersonal Trust in both Vertical and Horizontal Relationships from a Didirectional Perspective,' Public Management Review, 0(0), pp. 1-18.

Hassard, J. et al. (2018) 'The Cost of Work-Related Stress to Society: A Systematic Review', Journal of Occupational Health Psychology, 23(1), pp. $1-17$.

International Council on Mining \& Metals (2020) Improving Employee Mental Health and Wellbeing in the Mining Industry. United Kingdom : ICMM.

Jain, A. K. (2016) 'The Mediating Role of Job Satisfaction in the Relationship of Vertical Trust and Distributed Leadership in Health Care Context', Journal of Modelling in Management, 11(2), pp. 722-738.

Karasel, N. et al. (2018) 'Paternalist Leadership Style of the Organizational Trust', Quality and Quantity, 52, pp. 11-30.

Latif, M. (2018) 'The Impact of Charismatic Leadership on the Organization', Journal of Islam and Science, 3(2), pp. 204-217.

Lestari, K. S. et al. (2020) 'Causative Factor of Fatigue Levels in Copper and Gold Ore Mine 
Processing Workers', Journal of Community Health, 6, pp. 109-114.

Lewicka, D. and Pec, M. (2019) 'The Impact of Human Resources Management on Job Involvement. The Mediating Role of Vertical Trust', Folia Oeconomica Stetinensia, 18(2), pp. 34-45.

Ministry of Manpower of the Republic of Indonesia (2018) Peraturan Menteri Ketenagakerjaan Republik Indonesia Nomor 5 Tahun 2018 Tentang Keselamatan dan Kesehatan Kerja Lingkungan Kerja: Jakarta: Ministry of Manpower of the Republic of Indonesia.

Minerals Council of Australia (2015) 'Blueprint for Mental Health and Wellbeing'. Australia: Minerals Council of Australia.

Naciri, A. et al. (2020) 'National Guidelines on Management of Coronavirus Disease COVID-19 in Morocco', European Journal of Medical and Educational Technologies, 13(1), pp. 1-3.
Presiden Republik Indonesia (1970) Undang Undang Republik Indonesia Nomor 1 Tahun 1970 Tentang Keselamatan Kerja.

Ramdoo, I. (2020) 'The Impact of Covid-19 on Employment in Mining', Intergovernmental Forum, 0(0),pp. 1-6.

Rosari, R. (2019) 'Leadership Definitions Applications for Lecturers' Leadership Development', Journal of Leadership in Organizations, 1(1), pp. $17-28$.

Stedham, Y. and Skaar, T. (2019) 'Mindfulness, Trust, and Leader Effectiveness: A Conceptual Framework,' Frontiers in Psychology, 10(10), pp. 1-11.

Stoewen, D. L. (2016) 'Wellness at Work: Building Healthy Workplaces', The Canadian Veterinary Journal, 57(11), pp. 1188-1190.

The Australian Institute of Health and Welfare (2021) Mental health services in Australia. Australia: Australian Government. 